\title{
Problematika Layanan Digital Perpustakaan Institut Agama Islam Negeri Curup dalam Meningkatkan Pemanfaatan Karya Ilmiah Institusi
}

\author{
Rahmat Iswanto \\ Institut Agama Islam Negeri (IAIN) Curup \\ e-mail: rahmatiswanto.database@gmail.com
}

\begin{abstract}
The article about the problems of the digital service of the library of IAIN Curup aims to find the real problems in developing this service. The difference between the concepts by the experts and the phenomena that occurred in the library of IAIN Curup led the author to carry out this research. The problem raised is how digital service in college libraries, how digital service in the library of IAIN Curup is and what problems are found in the field. This research method was carried out by analyzing the data qualitatively then giving an interpretation related to the existing concept. Data managed by the authors was one of the results of field observations and direct interviews with librarians related to the digital service of the library of IAIN Curup. The results found that many elements must be fulfilled by the library of IAIN Curup to build digital service. The identification of the problems in this study is the answer to the purpose of this study.
\end{abstract}

Key Words: Academic Library; Digital Service; Digital Service's Problems

\begin{abstract}
Abstrak
Tulisan mengenai problematika layanan digital perpustakaan IAIN Curup bertujuan untuk menemukan permasalahan sesungguhnya dalam mengembangkan layanan ini. Terjadinya perbedaan antara konsep yang dituangkan oleh para ahli dan fenomena yang terjadi di perpustakaan IAIN Curup menggiring penulis melakukan penelitian ini. Permasalahan yang diangkat adalah bagaimana layanan digital di perpustakaan perguruan tinggi, bagaimana layanan digital yang ada di perpustakaan IAIN Curup dan problematika apa yang ditemukan di lapangan. Metode penelitian ini dilakukan dengan menganalisa data secara kualitatif kemudian memberikan interpretasi berkaitan dengan konsep yang ada. Data yang dikelola oleh penulis adalah hasil observasi di lapangan dan wawancara langsung dengan pustakawan yang terkait dengan layanan digital perpustakaan IAIN Curup. Hasil yang ditemukan bahwa banyak unsur-unsur yang harus dipenuhi oleh perpustakaan IAIN Curup untuk membangun layanan digitalnya. Identifikasi
\end{abstract}


permasalahan dalam penelitian ini menjadi jawaban atas pertanyaan penelitian ini.

Kata Kunci : Perpustakaan Perguruan Tinggi; Layanan Digital; Problematika Layanan Digital

\section{A. PENDAHULUAN}

Fungsi perpustakaan sebagai penyedia sumber informasi bagi pemustakanya semakin berperan seiring dengan perkembangan sumber informasi itu sendiri. Perpustakaan perguruan tinggi menempati fungsi yang sangat penting baik sebagai penyedia sumber informasi maupun mengolah dan menyebarkan sumber informasi yang semakin berkembang. Semakin lama penyelenggaraan sebuah perguruan tinggi maka semakin banyak pengembangan kajian keilmuan yang menghasilkan karya-karya intelektual perguruan tinggi tersebut. Karya-karya ini menjadi obyek tugas perpustakaan selain sumber informasi eksternal institusi.

Hal-hal baru berkaitan dengan ilmu yang dikembangkan akan ditemukan dan pengembangan terhadap hal-hal tersebut terjadi. Sumber informasi ilmiah yang dimiliki perguruan tinggi tersebut kemudian disebut dengan institusional intelektual research atau hasil penelitian ilmiah institusi.

Bentuk sumber informasi yang dikelola oleh perpustakaan tidak hanya bahan pustaka tercetak, akan tetapi bahan pustaka yang berbentuk digital menjadi obyek yang menarik seiring begitu banyaknya ketersediaan informasi berbentuk digital. Perkembangan sumber daya informasi berbentuk digital begitu cepat dengan beberapa gerakan ilmiah yang terjadi. Gerakangerakan tersebut antara lain kebutuhan sumber digital dari penyedia informasi ilmiah internasional yang sanggup dilanggan oleh perguruan tinggi, lahirnya jurnal-jurnal ilmiah open access, karya penelitian sivitas akademika seperti skripsi, thesis, desertasi, simposium, dan penelitian dosen serta didukung oleh gerakan pemeriksaan similarity untuk anti plagiasi.

Peran perpustakaan perguruan tinggi dalam memenuhi fungsinya terkait dengan pemanfaatan sumber informasi karya ilmiah institusi menjadi hal yang penting, bukan hanya untuk meningkatkan pemenuhan kebutuhan pemustaka akan tetapi juga memberikan sumbangsih untuk meningkatkan dan mempertahankan nilai lembaga perguruan tinggi induknya.

Seiring dengan perkembangan perpustakaan digital di Indonesia, pengelola perpustakaan perlu mengikuti trend pengembangan sistem dan layanan perpustakaan digital di masa mendatang. Pengembangan sistem dan 
layanan perpustakaan digital ini tentunya dapat memberikan manfaat dan dampak yang positif bagi kehidupan masyarakat. Hal yang perlu diperhatikan bahwa keberadaan perpustakaan digital ini sangat erat kaitannya dengan kehidupan masyarakat, khususnya dalam hal peningkatan kapasitas sosial masyarakat (Nashihuddin \& Saiful).

Dalam menjalankan perannya, perpustakaan perguruan tinggi dihadapkan kepada banyak tugas atau kegiatan yang harus dikelola dengan baik sehingga fungsi perpustakaan akan terwujud dengan baik pula. Kegiatan pokok perputakaan sudah cukup membutuhkan perhatian dalam memperbaiki kinerja perpustakaan dari waktu ke waktu sampai kepada manajemen kegiatan yang stabil dan bernilai positif. Sehingga dengan demikian untuk mengembangkan bentuk layanan lain akan membutuhkan suatu strategi yang baik berdasarkan analisa yang akurat dan terukur. Begitu pula dengan layanan digital di perpustakaan IAIN Curup, perlu mendapatkan perhatian dalam mengembangkan layanan ini.

Hingga sat ini, menurut pengamatan penulis penyediaan layanan digital di perpustakaan IAIN Curup masih belum memiliki enteti maupun eksistensi yang baik. Hal ini didasarkan atas beberapa faktor antara lain, belum ada database yang siap untuk diakses pemustaka dan belum adanya pelayanan melalui perangkat yang disediakan oleh perpustakaan sementara perpustakaan sudah mempersiapkan layanan digital untuk koleksi skripsi sudah dimulai semenjak perpustakaan memberikan kebijakan bahwa seluruh mahasiswa yang telah menyelesaikan studinya diwajibkan menyerahkan hasil penulisan skripsi berbentuk digital.

Dengan demikian pengembangan layanan seperti pemanfaatan karya ilmiah institusi melalui layanan digital memiliki kendala dalam beberapa hal. Untuk dapat menggali permasalahan sesungguhnya dalam hal ini penulis berusaha menuangkan sebuah kajian tentang problematika layanan digital perpustakaan IAIN Curup dalam meningkatkan pemanfaatan karya ilmiah institusi.

Beberapa penelitian terdahulu memberikan suatu kesimpulan yaitu antara lain bahwa dengan pesatnya perkembangan teknologi informasi dan beragam, oleh karenanya seyogyanya pustakawan sebagai pekerja informasi memiliki kompetensi atau kemampuan diri dalam mengakses dan mengidentifikasi sumber informasi, yang valid, yang reliable dan yang akurat sesuai dengan kebutuhan pemustaka. Saran yang diberikan kepada pustakawan yakni; (1) Mengadakan workshop, training dan sejenisnya mengenai digital literasi, (2) Dalam kurikulum pendidikan perpustakaan, 
digital literasi bisa menjadi subjek tersendiri dalam mata pelajaran mengingat pesatnya perkembangan teknologi tersebut saat ini (Wahyudi, 2017).

Dalam tulisan lain, melihat bagaimana peningkatan bibliometrik melalui layanan digital. Sebagaimana digambarkan : the study aims to identify the degree of authors collaboration among scholars in digital hiteracy articles published from 1997-2013. The 661 digital literacy articles were gathered and indexed by web of science. The study found that the degree of author collaboration was 0.62 or $62 \%$, indicating that more than a half of 661 articles were multi-authored papers. In addition, America Continents have proportionally contributed in discussing about digital literaty topic. It was then followed by European countries, Australia/Oceania, Asia, and Africa respectively. The study also figured out that Eszter Hargittai was the most prolific author who was published 8 articles in different journals on this particular topic (Taufiq, 2014).

Representasi tingkat kepuasan pemustaka terhadap efektivitas pemanfaatan sistem informasi perpustakaan digital pada Perpustakaan Perguruan Tinggi Islam di Yogyakarta. Dalam tulisannya "Representasi tingkat kepuasan pemustaka terhadap efektivitas pemanfaatan sistem informasi perpustakaan digital pada Perpustakaan Perguruan Tinggi Islam di Yogyakarta", Penulis memberikan saran sebagai berikut (1). Perlu melayankan koleksi digital dalam format full-teks untuk memenuhi kebutuhan informasi kepada pemustaka secara menyeluruh dan menyongsong open access movement. (2). Proses entri koleksi sebaiknya dilakukan secara spontanitas secara menyeluruh, bukan secara bertahap. (3). Perlu ditambah fitur controled vocabulary. (4). Perlu ditambah fitur spell checker untuk meminimalisir kesalahan penulisan pada search box (Mukhlis, 2015).

Tulisan lain memberikan kesimpulan berkaitan dengan kebutuhan manajemen perpustakaan dalam mewujudkan pelayanan prima yaitu dengan meningkatkan kualitas pustakawannya. Kualitas pustakawan dapat dicapai dengan memenuhi kriteria, standar profesi serta etika pustakawan (Andi, 2014).

Dalam mengantisipasi perkembangan teknologi informasi, banyak pekerjaan yang harus dilakukan oleh pustakawan terutama dalam meningkatkan kopetensi penguasaan teknologi tersebut. Usaha yang dapat dilakukan berkomunikasi aktif dengan pakar teknologi dan melakukan pelatihan. Sehingga layanan yang berbasis teknologi akan diberikan secara maksimal (Nugrohoadhi, 2013). 
Pada tulisan lain, peningkatan pelayanan sumber informasi di perpustakaan sangat perlu dilaksanakan termasuk pelayanan digital. Layanan digital di perpustakaan IAIN Curup pada hakekatnya sangat mendukung kualitas penyelenggaraan program studi. Pada akhir studi mahasiswa sangat membutuhkan karya-karya ilmiah terdahulu sehingga konten digital yang diharapkan menjadi koleksi yang populer dan digemari mahasiswa. Sementara hal-hal lain sangat potensial untuk dapat diwujudkaan. Dalam penelitiannya, diidentifikasi bahwa kendala yang dihadapi dapat diatasi dengan proses evaluasi teratur, komunikasi yang baik, dukungan pihak pimpinan dan penyediaan fasilitas dan SDM khusus. Demikian juga halnya dengan persiapan layanan digital (Iswanto, 2017).

Rumusan permasalahan dalam tulisan ini adalah bagaimana layanan digital perpustakaan perguruan tinggi; bagaimana layanan digital perpustakaan IAIN Curup; apa problematika layanan digital perpustakaan IAIN Curup.

Metode yang digunakan dalam tulisan ini adalah deskriptif kualitatif. Penulis mengumpulkan data dari sumbernya dengan teknik observasi dan interview. Kemudian data yang diperoleh dikelola secara sistematis berdasarkan faktor-faktor yang terkait dan memberikan interpretasi secara kualitatif dengan ukuran teori-teori yang berlaku.

\section{B. HASIL DAN PEMBAHASAN}

\section{Problematika}

Makna problematika atau problematik dalam kamus besar Bahasa Indonesia adalah problematik/pro.ble.ma.tik//problématik/ 1 a masih menimbulkan masalah; $2 n$ hal yang masih belum dapat dipecahkan; permasalahan (KBBI-Online). Sementara dalam Kamus Besar Bahasa Indonesia versi tercetak definisinya adalah problema berarti hal yang belum dapat dipecahkan; yang menimbulkan permasalahan (Debdikbud, 2002).

Sedangkan ahli lain mengatakan menyatakan bahwa "definisi problema/problematika adalah suatu kesenjangan antara harapan dan kenyataan yang diharapkan dapat menyelesaikan atau dapat diperlukan atau dengan kata lain dapat mengurangi kesenjangan itu"(Syukir, 1983). Jadi problema adalah berbagai persoalan-persoalan yang sulit yang dihadapi dalam proses pemberdayaan. 


\section{Perpustakaan Digital}

Perpustakaan Digital merupakan terjemahan dari Digital Library. Istilah tersebut digunakan untuk menjelaskan dan mengungkapkan model dan konsep perpustakaan digital yang juga disebut perpustakaan elektronik, perpustakaan hibrida, perpustakaan maya, atau pun perpustakaan tanpa dinding. Istilah ini muncul juga dalam bahasa Inggeris dan sering orang sering menyebutkannya yaitu electronic library, virtual library, hybrid library. Istilah perpustakaan digital lebih sering digunakan dalam kegiatan ilmiah di bidang perpustakaan seperti seminar, workshop, simposium atau konferensi. Defisini tentang perpustakaan digital tidaklah seragam. Digital Library Federation di Amerika Serikat memberikan defisini perpustakaan digital sebagai organisasi-organisasi yang menyediakan sumber-sumber, termasuk staff dengan keahlian khusus, untuk menyeleksi, menyusun, menginterpretasi, memberikan akses intelektual, mendistribusikan, melestarikan dan menjamin keberadaan koleksi karya-karya digital sepanjang waktu sehingga koleksi tersebut dapat digunakan oleh komunitas masyarakat tertentu (Siregar).

Romi Satrio Wahono (1999) mendefinisikan perpustakaan digital sebagai suatu perpustakaan yang menyimpan data baik itu buku (tulisan), gambar, suara dalam bentuk file elektronik dan mendistribusikannya dengan menggunakan protokol elektronik melalui jaringan komputer. Menurutnya, istilah perpustakaan digital memiliki pengertian yang sama dengan perpuetakaan elektronik (electronic library) dan perpustakaan maya (virtual library) (Wahono).

Digital library adalah organisasi yang menyediakan sumber dan staf ahli untuk menyeleksi, menyusun, menyediakan akses, menerjemahkan, menyebarkan, memelihara kesatuan dan mempertahankan kesinambungan koleksi-koleksi dalam format digital sehingga selalu tersedia dan mudah untuk digunakan oleh komunitas tertentu.

Pengembangan layanan perpustakaan digital (digital library) harus diawali dengan pengembangan SDM yang ada di perpustakaan. Hal ini perlu dilakukan karena saat ini bidang Teknologi Informasi dan komunikasi (Information Technology and Communication) sudah menjadi kebutuhan pokok perpustakaan.

Perpustakaan digital menurut Sulistyo Basuki dan Winy Purtini digagas pertama kali oleh Vannenar Bush pada awal tahun 1940-an (Arif, 2005). Vannenar Bush sebagai penasehat Presiden Rosevelt bidang ilmu pengetahuan, dia menghadapi masalah banyaknya informasi dan masih 
disimpan dalam bentuk analog. Keadaan saat itu menyulitkan dalam akses informasi terutama hasil penelitian yang sudah dipublikasikan. Berangkat dari keadaan itu dia menganggas "thinking machine" dan sebuah device disebut MemEx yang memungkinkan seseorang menyimpan buku, record dalam komunikasinya. MemEx kemudian dimekanisasi sehingga memungkinkan konsultasi informasi yang cepat dan fleksibel. Pada awal tahun 1980-an beberapa perpustakan besar melaksanakan otomasi fungsifungsi perpustakaan karena masih mahalnya harga perangkat komputer. Pada tahun 90-an hampir semua fungsi-fungsi perpustakaan telah diotomasi, serta berkembangnya komunikasi data antar perpustakaan secara elektronik.

Menurut Wahono (1999), Tahun 1991 delapan universitas yaitu: Carnegie Mellon University, Cornel University, GIT, MIT, University of California, University of Tennesee, University of Qoashington, Virinia Polytechnic dan State Unibersity bersama Elsevier Science mengadakan kesepakatan kerjasama pengembangan perpustakaan digital yang dikenal dengan nama TULIP (The University Licensing Project) (Wahono).

Pengembangan perpustakaan digital tidak dapat dilakukan secara sembarangan, tetapi perlu suatu formulasi yang terencana dengan rapi. Pengembangan ini menyangkut banyak aspek yang ada di perpustakaan. Formulasi yang dimaksud adalah adanya suatu perencanaan secara menyeluruh terhadap berbagai aspek yang melingkupi suatu perpustakaan. Perencanaan ini diperlukan untuk mentransformasikan sistem dari sistem layanan perpustakaan yang konvensional (tradisional) berbasis koleksi analog ke perpustakaan digital. Pengembangan layanan perpustakaan digital perlu mentransformasikan antara lain: formulasi kebijakan, perencanaan strategis, standarisasi, pengembangan koleksi, infrastruktur jaringan, metode akses, pendanaan, kolaborasi, control bibliografi dan pelestarian untuk menuju keberhasilan dalam pengembangan ke format digital (Supriyanto).

Sejalan dengan pertumbuhan dan perkembangan program-program perpustakaan digital. Perpustakaan perlu menyiapkan ruangan yang secara khusus dirancang untuk menyimpan data buku, tulisan, gambar dan suara dalam bentuk elektronik yang dapat diakses menggunakan internet, serta pengalihan dana dari pengadaan bahan pustaka tercetak ke dalam pustaka elektronik (digital).

Perubahan model belajar yang selama ini hanya di ruang kelas dengan gaya ceramah yang sifatnya tradisional berubah ke ruang kelas elektronik yang terhubung dengan jaringan komputer dengan perlengkapan multimedia sehingga memungkinkan "sistem belajar jarak jauh". Oleh karena 
itu dibutuhkan pengembangan sistem dan metoda pelayanan perpustakaan yang efisien dan efektif dengan bobot materi informasi yang terpercaya. Semua hal tersebut hendaknya dilakukan oleh instansi/lembaga penyedia informasi secara sinergi untuk meningkatkan kepercayaan masyarakat terhadap instansi/ lembaga penyedia informasi baik di pusat maupun di daerah. Kemajuan Teknologi dan persaingan bisnis memaksa organisasi menata ulang sistem teknologi informasi Organisasi memanfaatkan sistem teknologi informasi (STI) untuk mengimplementasikan strateginya. Sistem teknologi informasi merupakan senjata stratejik (strategic weapon). Sistem teknologi informasi untuk memenangkan persaingan organisasi. Tuntutan ketersediaan informasi dalam sebuah sistem informasi berbasis komputer dengan tingkat otomasi yang tinggi Sistem layanan perpustakaan manual dengan penggunaan kertas yang banyak seringkali menyulitkan pengguna aksesibilitas informasi.

Pengembangan perpustakaan digital merupakan respon atas lahirnya undang-undang nomor 43/2007 yang bertujuan :

1. Meningkatkan akses ke sumberdaya informasi yang tersedia dan layanan perpustakaan yang diselenggarakan oleh perpustakaan yang tergabung dalam jaringan (resource sharing). Pembangunan perpustakaan digital agar supaya koleksi perpustakaan tersebut cepat dan mudah diakses, ringkasi dalam penyimpanan serta mudah dalam hal penggandaan. Keberhasilan perpustakaan digital dapat diukur dari kemudahan akses bagi penggunanya, bukan semata-mata mahalnya pengadaan. Dalam perpustakaan digital yang dikerjakan pustakawan adalah tentang metadata untuk kepentingan pencatatan dengan baik, menyimpan dengan tepat dan menemukan kembali dengan mudah.

2. Menyediakan sumber belajar, mendorong ketersediaan bahan pustaka dan informasi yang mengandung nilai budaya setempat (local content)

3. Melestarikan sumber informasi tentang budaya Indonesia

4. Mendukung penelitian ilmiah melalui internet.

Perpustakaan digital dimaknakan berbeda dengan layanan digital. Persamaannya adalah pada koleksi yang disediakan untuk pemustaka. Jika berbicara dengan perpustakaan digital maka yang dimaksudkan adalah keseluruhan koleksi yang disediakan oleh perpustakaan itu berbentuk digital. Sementara layanan digital maksudnya sebagian koleksi sebuah perpustakaan berbentuk digital dan diberikan pelayanan terhadap koleksi tersebut.

Perpustakaan digital atau layanan digital bagi perpustakaan memberikan manfaat yang cukup besar termasuk untuk membangun jaringan 
kerjasama antar perpustakaan dalam hal pemanfaatan koleksinya. Konsep peminjaman antara perpustakaan (inter-library loan) yang lama menjadi wacana, akan menjadi mudah dengan hadirnya koleksi digital. Hal ini karena keterhubungan komputer-komputer penyimpan koleksi melalui internet sehingga mudah untuk mengunduhnya atau memanfaatkannya (Pendit, Suryandari, \& al., 2007).

\section{Layanan Digital Perguruan Tinggi}

Layanan digital adalah bentuk layanan perpustakaan yangmana koleksi atau sumber informasi yang disajikan berbentuk digital. Berbeda dengan istilah perpustakaan digital, layanan digital merupakan bagian dari layanan yang diberikan oleh sebuah perpustakaan. Perpustakaan digital diartikan secara proporsional berarti sebuah perpustakaan yang semua koleksinya berbentuk digital. Sementara layanan digital hanya bagian dari sebuah perpustakaan. Perpustakaan digital memiliki layanan digital pada seluruh layanan yang disediakan. Layanan digital dapat ditemukan pada sebuah perpustakaan biasa.

Layanan digital pada perpustakaan perguruan tinggi biasanya untuk jenis koleksi karya institusi yang dibentuk digital seperti skripsi, tesis dan disertasi. Meskipun demikian ada layanan digital lain yang selain karya institusi misalnya melanggan database tertentu yangmana koleksi atau sumber informasi berbentuk digital atau elektronik.

Untuk membuat layanan digital hal-hal penting yang harus dipersiapkan adalah pengguna, pustakawan (petugas), perangkat keras, perangkat lunak, pangkalan data, jaringan, petunjuk pelayanan, lokasi (space) layanan.

Layanan digital di perpustakaan muncul dan berkembang dengan berkembangnya teknologi dan bentuk media informasi. Urgensi keberadaan layanan digital dikategorikan kepada beberapa keadaan. Layanan digital dianggap sangat penting jika dikaitkan dengan bentuk digitalisasi karya institusi karena pertimbangan antara lain untuk memudahkan penyimpanan karya institusi, menghemat ruang perpustakaan, memudahkan temu kembali, membantu mencegah aksi plagiasi di kalangan kampus, serta membantu mengarahkan bentuk dan tema penelitian sebuah kajian keilmuan yang sedang dikembangkan. Layanan digital bentuk lain seperti melanggan database dianggap masih belum begitu penting disebabkan besaran anggaran yang dimiliki institusi belum mendukung untuk itu. 
Pada perpustakaan perguruan tinggi yang sudah besar, memiliki pelayanan penyediaan sumber informasi atau bentuk bahan pustaka yang mutakhir. Melalui teknologi yang berkembang dan dikembangkan, perpustakaan tersebut membangun sebuah data base koleksi digital dengan menggunakan aplikasi open source sehingga bentuk penyediaan bahan pustaka lebih luas. Keberadaan layanan digital untuk karya institusi terbukti efektif menaikkan rating bibliometiks perguruan tinggi tersebut dikarenakan gerakan pengutipan akan terjadi dengan intensitas yang lebih tinggi.

Tidak semua perpustakaan perguruan tinggi telah mampu membangun layanan digital seperti yang digambarkan di atas. Hal tersebut dikarenakan keterbatasan sumber daya manusia dan peran perpustakaan perguruan tinggi dalam memodifikasi serta mengembangkan layanannya.

Sistem informasi perpustakaan digital UIN Sunan Kalijaga dapat diakses dengan laman www.digilib.uin-suka.ac.id, pada portal tersebut pemustaka dapat menggunakan/ mengimplementasikan dengan cara sebagai berikut: (1) Koleksi "digital" yang bisa diakses melalui jaringan seperti: skripsi, tesis, disertasi, laporan penelitian dan lain sebagainya. (2) Tersedia fasilitas untuk searching dan retrieval informasi. (3) Memiliki konten koleksi, baik format yang berupa data maupun metadata. (4) Untuk mengakses data secara full-text (khususnya tugas akhir mahasiswa, skripsi, tesis, disertasi, dsb), perpustakaan digital UIN Sunan Kalijaga Yogyakarta mewajibkan kepada pengguna untuk melakukan registrasi terlebih dahulu untuk mendapatkan username dan password, untuk koleksi yang non full-text, pengguna bisa mengakses secara langsung tanpa harus login terlebih dahulu (Mukhlis, 2015). Representasi tingkat kepuasan pemustaka terhadap efektivitas pemanfaatan sistem informasi perpustakaan digital pada Perpustakaan Perguruan Tinggi Islam di Yogyakarta. Dalam tulisannya "Representasi tingkat kepuasan pemustaka terhadap efektivitas pemanfaatan sistem informasi perpustakaan digital pada Perpustakaan Perguruan Tinggi Islam di Yogyakarta", Penulis memberikan saran sebagai berikut (1). Perlu melayankan koleksi digital dalam format full-teks untuk memenuhi kebutuhan informasi kepada pemustaka secara menyeluruh dan menyongsong open access movement. (2). Proses entri koleksi sebaiknya dilakukan secara spontanitas secara menyeluruh, bukan secara bertahap. (3). Perlu ditambah fitur controled vocabulary. (4). Perlu ditambah fitur spell checker untuk meminimalisir kesalahan penulisan pada search box.

\section{Layanan Digital Perpustakaan IAIN Curup}

Perpustakaan IAIN Curup memberikan layanan digital kepada pemustaka pada koleksi institusi khususnya karya ilmiah berupa skripsi mahasiswa. Perpustakaan membangun pangkalan data koleksi digital skripsi 
yang dapat diakses oleh mahasiswa. Pangkalan data yang dibangun melalui aplikasi yang kemudian bernama repositori institusi. Hanya saja dalam proses membangunnya masih terkendala dalam banyak hal. Selain bentuk koleksi yang merupakan digitalisasi karya ilmiah mahasiswa, perpustakaan IAIN Curup juga menjalin kerja sama untuk menyediakan koleksi digital kepada pemustakanya.

\section{Problematika Layanan Digital Perpustakaan IAIN Curup}

Berdasarkan unsur penting dalam pembentukan layanan digital, maka problematika yang dijumpai dalam layanan digital perpustakaan IAIN Curup adalah sebagai berikut:

Pengguna, perpustakaan IAIN Curup memiliki pengguna yang sangat membutuhkan koleksi digital khususnya mahasiswa yang sedang menulis karya ilmiah atau laporan akhir studi. Penguna lain untuk layanan ini adalah pihak yang berkepentingan menilai karya ilmiah mahasiwa dari segi plagiasi yaitu pengelola program studi.

Berdasarkan hasil observasi penulis, mahasiswa yang membutuhkan koleksi karya ilmiah dari semua program studi yang sedang menulis. Statistik pengunjung cukup ramai yaitu rata-rata 50 pengunjung setiap hari. ${ }^{1}$

Pustakawan (petugas), untuk membangun layanan digital ini, perpustakaan IAIN Curup harus menyiapkan petugas khusus atau pustakawan khusus. Hal ini karena proses membangun pangkalan data yang bertahap dan berstandar serta dengan kegiatan yang rutin memungkinkan mendapatkan data untuk mengevaluasi pelayanan tersebut.

Begitu pesatnya perkembangan teknologi informasi dan beragam, oleh karenanya seyogyanya pustakawan sebagai pekerja informasi memiliki kompetensi atau kemampuan diri dalam mengakses dan mengidentifikasi sumber informasi, yang valid, yang reliable dan yang akurat sesuai dengan kebutuhan pemustaka. Saran yang diberikan kepada pustakawan yakni; (1) Mengadakan workshop, training dan sejenisnya mengenai digital literasi, (2) Dalam kurikulum pendidikan perpustakaan, digital literasi bisa menjadi subjek tersendiri dalam mata pelajaran mengingat pesatnya perkembangan teknologi tersebut saat ini (Wahyudi, 2017).

Berdasarkan observasi penulis, pustakawan yang memberikan layanan khusus untuk karya ilmiah skripsi belum ada. Pustakawan yang ada memberikan layanan karya referensi dan karya ilmiah skripsi. ${ }^{2}$

\footnotetext{
${ }^{1}$ Data statistik layanan lantai 3 (karya ilmiah dan karya referensi) bulan Februari 2019
} 
Pangkalan data, ketersediaan pangkalan data memungkinkan pengguna mendapatkan informasi terkait dengan konten pangkalan data tersebut. Konten pangkalan data yang dimaksud adalah seluruh karya ilmiah mahasiswa yang telah menyelesaikan penulisannya dari berbagai program studi yang ada di IAIN Curup.

Koleksi yang digunakan di perpustakaan IAIN Curup adalah koleksi yang tercetak sementara yang berbentuk digital belum dapat diakses oleh pemustaka. $^{3}$

Perangkat keras, perangkat ini sangat penting untuk menyimpan pangkalan data dan proses penelusuran informasi yang ada di dalam pangkalan data.

Berdasarkan observasi penulis, perpustakaan IAIN Curup belum memiliki perangkat keras untuk layanan digital karya ilmiah mahasiswa. ${ }^{4}$

Perangkat lunak, aplikasi yang dibutuhkan untuk membangun pangkalan data ada yang disediakan secara open source. Aplikasi ini dijalankan dengan prosedur tertentu berdasarkan fitur-fitur yang dikreasikan dan dijalankan oleh pustakawan yang telah dilatih sebelumnya.

Perangkat lunak yang digunakan perpustakaan IAIN Curup untuk membangun pangkalan data sudah dimiliki. Hanya saja proses membangunnya belum ada pustakawan yang dilatih untuk penggunaannya. ${ }^{5}$

Jaringan, koneksi antara server dan perangkat yang digunakan pemustaka serta akses secara online dibutuhkan dalam menjalankan layanan digital.

Perpustakaan memiliki jaringan online untuk akses, akan tetapi belum memiliki perangkat yang dapat dijadikan server maupun untuk akses. ${ }^{6}$

Lokasi (space) layanan, pelayanan koleksi digital membutuhkan lokasi yang memadai baik untuk perangkat dalam proses penelusuran maupun lokasi untuk melakukan akses dan menggunakan informasi yang didapatkan.

\footnotetext{
${ }^{2}$ Observasi penulis Maret 2019 pada perpustakaan IAIN Curup

${ }^{3}$ Hasil wawancara dengan pustakawan lantai 3(karya ilmiah dan karya referensi) bulan Februari 2019

${ }^{4}$ Observasi penulis Maret 2019 pada perpustakaan IAIN Curup

${ }^{5}$ Hasil wawancara dengan pustakawan lantai 3(karya ilmiah dan karya referensi) bulan Februari 2019

${ }^{6}$ Hasil wawancara dengan pustakawan lantai 3(karya ilmiah dan karya referensi) bulan Februari 2019
} 
Perpustakaan IAIN Curup belum memiliki lokasi yang memadai dalam hal menyediakan kelayakan pelayanan koleksi digital karya ilmiah mahasiswa. ${ }^{7}$

Petunjuk pelayanan, perpustakaan menetapkan bentuk pelayanan pada seluruh bagian yang disiapkan termasuk layanan digital. Petunjuk pelayanan mencakup prosedur penggunaan layanan, bentuk-bentuk pelayanan, hak dan kewajiban pemustaka.

Perpustakaan IAIN Curup belum memiliki petunjuk pelayanan ini secara khusus karena pelayanan yang dimaksudkan dikhususkan. ${ }^{8}$

Tabel : Problematika Layanan Digital dari Aspek Unsur Terlibat

\begin{tabular}{|l|l|l|}
\hline No. & \multicolumn{1}{|c|}{ Aspek } & \multicolumn{1}{|c|}{ Problematika } \\
\hline 1 & Pengguna & $\begin{array}{l}\text { Pemustaka tidak dapat mendapatkan koleksi } \\
\text { digital untuk penulisan tugas akhir dan } \\
\text { pengelola prodi belum dapat memanfaatkan } \\
\text { database koleksi untuk mengecek tindakan } \\
\text { plagiasi }\end{array}$ \\
\hline 2 & Pustakawan & $\begin{array}{l}\text { Pustakawan yang memberikan layanan khusus } \\
\text { untuk karya ilmiah skripsi belum ada }\end{array}$ \\
\hline 3 & Perangkat Keras & $\begin{array}{l}\text { Belum memiliki perangkat keras untuk } \\
\text { layanan digital karya ilmiah mahasiswa }\end{array}$ \\
\hline 4 & Perangkat Lunak & $\begin{array}{l}\text { Proses membangunnya belum ada pustakawan } \\
\text { yang dilatih untuk penggunaannya }\end{array}$ \\
\hline 5 & Pangkalan Data & $\begin{array}{l}\text { Koleksi yang berbentuk digital belum dapat } \\
\text { diakses oleh pemustaka }\end{array}$ \\
\hline 6 & Jaringan & $\begin{array}{l}\text { Belum memiliki perangkat yang dapat } \\
\text { dijadikan server maupun untuk akses }\end{array}$ \\
\hline 7 & Petunjuk Pelayanan & $\begin{array}{l}\text { Belum memiliki petunjuk pelayanan yang } \\
\text { khusus }\end{array}$ \\
\hline 8 & Lokasi Layanan & $\begin{array}{l}\text { Belum memiliki lokasi yang memadai dalam } \\
\text { hal menyediakan kelayakan pelayanan koleksi } \\
\text { digital karya ilmiah mahasiswa }\end{array}$ \\
\hline
\end{tabular}

${ }^{7}$ Observasi penulis Maret 2019 pada perpustakaan IAIN Curup

${ }^{8}$ Observasi penulis Maret 2019 pada perpustakaan IAIN Curup 
80 | Rahmat Iswanto : Problematika Layanan Digital...

Tabel : Problematika Layanan Digital dari Aspek Perencanaan

\begin{tabular}{|c|c|c|}
\hline No. & Aspek & Problematika \\
\hline 1 & $\begin{array}{l}\text { Formulasi/Bentuk } \\
\text { Kebijakan }\end{array}$ & $\begin{array}{l}\text { Bentuk kebijakan yang belum ditentukan } \\
\text { dengan baik sehingga perencanaan layanan } \\
\text { ini tidak berjalan }\end{array}$ \\
\hline 2 & $\begin{array}{l}\text { Renstra/Perencanaan } \\
\text { Strategis }\end{array}$ & $\begin{array}{l}\text { Perencanaan strategis terkait dengan layanan } \\
\text { ini yang belum disusun dengan baik } \\
\text { sehingga proses pembangunan layanan ini } \\
\text { tidak terukur }\end{array}$ \\
\hline 3 & rdisasi & $\begin{array}{l}\text { Belum ada sosialisasi stardardisasi pelayanan } \\
\text { digital perpustakaan }\end{array}$ \\
\hline 4 & $\begin{array}{l}\text { Pelaksanaan } \\
\text { Pengembangan } \\
\text { Koleksi }\end{array}$ & $\begin{array}{l}\text { Pengembangan koleksi tidak dipantau dari } \\
\text { perkembangan penyelesaian studi oleh } \\
\text { program studi yang ada di IAIN }\end{array}$ \\
\hline 5 & Infrastruktur Jaringan & Infrastruktur jaringan masih kurang \\
\hline 6 & Pola/Metode Akses & $\begin{array}{l}\text { Metode akses belum dibangun karena belum } \\
\text { adanya sistem jaringan yang dibangun }\end{array}$ \\
\hline 7 & Biaya/Pendanaan & $\begin{array}{l}\text { Belum ada biaya khusus untuk layanan ini } \\
\text { sampai kepada terciptanya layanan }\end{array}$ \\
\hline 8 & Kerjasama/Kolaborasi & Belum berjalan dengan baik \\
\hline 9 & $\begin{array}{ll}\text { Kontrol Data } \\
\text { Bibliografi }\end{array}$ & Belum berjalan dengan baik \\
\hline 10 & $\begin{array}{l}\text { Pelestarian Format } \\
\text { Digital }\end{array}$ & $\begin{array}{l}\text { Belum ada wadah yang sesuai dengan } \\
\text { standar penyimpanan koleksi media digital }\end{array}$ \\
\hline
\end{tabular}

\section{KESIMPULAN}

Layanan digital perpustakaan perguruan tinggi merupakan bentuk layanan yang sangat diperlukan oleh sivitas akademika. Layanan ini melengkapi pemenuhan kebutuhan sumber informasi bagi pemustaka selain koleksi tercetak. Banyak hal yang memiliki keunikan layanan digital yang tidak dimiliki oleh layanan tercetak. Keunikan ini menjadikan sebuah pilihan dan variasi bagi pemustaka dalam melengkapi informasi untuk kajian bidang keilmuan yang mereka kembangkan. Dengan manfaat tersebut banyak perpustakaan perguruan tinggi menyediakan layanan ini dengan mempersiapkan beberapa unsur pendukungnya yang antara lain pemustaka yang memputuhkan, pustakawan yang kompeten, perangkat keras, perangkat lunak, pangkalan data, jaringan, petunjuk pelayanan, lokasi (space) layanan. 
Pada tulisan lainnya, pengembangan layanan perpustakaan digital membutuhkan transformasi beberapa unsur antara lain formulasi/bentuk kebijakan, renstra/perencanaan strategis, standardisasi, pelaksanaan pengembangan koleksi, infrastruktur jaringan, pola/metode akses, biaya/pendanaan, kerjasama/kolaborasi, kontrol data bibliografi dan pelestarian format digital (Supriyanto).

Layanan digital perpustakaan IAIN Curup belum disediakan dengan baik hal ini disebabkan masih banyak hal-hal yang belum dimiliki. Perpustakaan IAIN Curup sudah memiliki program untuk menciptakan layanan digital, hanya saja hingga saat ini masih dalam tahap menghimpunan dokumen digital pada perangkat keras. Pemustaka perpustakaan IAIN Curup masih memanfaatkan layanan karya ilmiah institusi secara tercetak.

Problematika layanan digital perpustakaan IAIN Curup terletak pada sebagian besar unsur yang menunjang yaitu pustakawan yang kompeten, perangkat keras, perangkat lunak, pangkalan data, jaringan, petunjuk pelayanan, lokasi (space) layanan.

Melihat pentingnya layanan digital untuk kebutuhan mahasiswa, maka hendaknya perpustakaan melakukan persiapan yang matang dalam mewujudkannya. Aspek-aspek yang dibutuhkan dievaluasi dan dilakukan pengamatan dan penelitian sehingga pembangunan layanan ini akan semakin terukur.

\section{DAFTAR RUJUKAN}

Andi, I. (2014). Konsep dasar manajemen perpustakaan dalam mewujudkan mutu layanan prima dengan sistem temu kembali informasi berbasis digita. Khizanah Al-Hikmah, 129-138.

Arif, I. (2005). Sepintas tentang perpustakaan digital. Sangkala, 3-11.

Debdikbud. (2002). Kamus Besar Bahasa Indonesia. Jakarta: Bulan Bintang.

Iswanto, R. (2017). Peningkatan Program Studi Melalui Perencanaan Strategis dalam Pemenuhan Kebutuhan Sumber Informasi Kajian Keilmuan Sivitas Akademika (Analisis Pelaksanaan di Perpustakaan Sekolah Tinggi Agama Islam Negeri Curup). Tik Ilmeu, 145-160.

KBBI-Online. (n.d.). KBBI Online. Retrieved Mei 5, 2019, from https://kbbi.web.id/problematik 
Mukhlis. (2015). Representasi tingkat kepuasan pemustaka terhadap efektivitas pemanfaatan sistem informasi perpustakaan digital pada Perpustakaan Perguruan Tinggi Islam di Yogyakarta (studi kasus di Perpustakaan UIN Sunan Kalijaga Yogyakarta). Khizanah AlHikmah, 146-155.

Nashihuddin, W., \& Saiful, A. (n.d.). Optimasi Layanan Perpustakaan Digital untuk Peningkatan Kapasitas Sosial Masyarakat. Retrieved Januari 10, 2019, from https://www.researchgate.net/publication/321308494

Nugrohoadhi, A. (2013). Menakar peranan pustakawan dalam implementasi teknologi informasi di perpustakaan. Khizanah Al-Hikmah, 101-114.

Pendit, P. L., Suryandari, A., \& al., e. (2007). Perpustakaan digital : perspektif perpustakaan perguruan tinggi Indonesia. Jakarta: Sagung Seto.

Siregar, A. R. (n.d.). Perpustakaan Elektronik: definisi, karakteristik dan Penanganannya. Retrieved Desember 5, 2018, from http//www.akademik.unsri.ac.id/download/journal/files/bai-journal/

Supriyanto, W. (n.d.). Pengembangan Sistem Layanan Perpustakaan Digital. Retrieved April 1, 2019, from https://repository.ugm.ac.id/136541/

Syukir. (1983). Dasar-dasar strategi dakwah islami. Surabaya: Al-Ikhlas.

Taufiq, M. (2014). Authors collaboration in digital literacy from 1997 to 2014: a bibliometric study. Khizahan Al-Hikmah : Jurnal Ilmu Perpustakaan \& Kearsipan, 158-169.

Wahono, R. S. (n.d.). Digital library dan proyek-proyek penelitiannya. Retrieved Januari 10, 2018, from Romisatriawahono.net/publications/1999/romi-dimensi3-99.pdf

Wahyudi. (2017). Pentingnya keterampilan digital literasi bagi pustakawan. . Khizanah al-Hikmah : Jurnal Ilmu Perpustakaan, Informasi, dan Kearsipan., 187-195. 